\title{
Entrepreneurial Spirit of The Entrepreneurs and Non-Entrepreneurs Millennials
}

\author{
Genoveva Genoveva and Jason Tanardi
}

\begin{abstract}
This research aims to analyze the entrepreneurial spirit of millennials both of the entrepreneur and the nonentrepreneur. The respondents of this research were the alumni of President University, as all of the alumni during their study in President University got the entrepreneurship subject as one of the university mandatory subject. Respondents data were collected by an online questionnaire, using the Google form. The valid data as much as 170 and processed with SPSS version 22. The result of the study shows that, there are differences of non-entrepreneur millennials and entrepreneur millennials. In correlation there is a positive and strong correlation of Passion, Innovation, Adaptability, Sustainability and Competitiveness to Performance of Entrepreneur and Non-Entrepreneur millennials. By descriptive analysis, millennials of the Non-Entrepreneurs have a higher mean compared with the millennials who are entrepreneurs.
\end{abstract}

Index Terms - Millennial, Passion, Innovation, Adaptability, Sustainability, Competitiveness.

\section{INTRODUCTION}

Entrepreneurial spirit is very important for both entrepreneur and corporate entrepreneur, because the entrepreneurial spirit consist of innovation, creativity, leadership, team work, communication skills and as an agent of change. It can be said that the entrepreneurial spirit is not only needed by an entrepreneur but also a manager in bringing his company to compete. Drucker (1985) said that in order to compete, a company must change and innovate or having an intrapreneurship skill.

According to Wirawan (2012) entrepreneurs spirit has a positive impact for its internal or external side. It makes more interesting because intrapreneurial spirit could increase the advantage of its cooperation where they are working for and the company could compete strongly. Various definitions have been presented in decades, intrapreneurship is defined as an entrepreneurial spirit within the company or organization where a person works, where the behavior refers to the motivation of the individual in making his contribution to the company in accordance with their respective roles.

Intrapreneurship includes not only generating new ideas and works, but also other innovative activities such as creating new products, creations in services, technology, administrative procedures, and strategies that can compete.

Previous research from the current researcher and the partner, Gracia and Genoveva (2018) found that mostly the

Published on February 27, 2020

Genoveva Genoveva, President University, Indonesia.

(e-mail: genoveva@president.ac.id).

Jason Tanardi, President University, Indonesia.

(e-mail: jasontanardi5@gmail.com).
Human Resources department will recruit the managers who have the entrepreneurial spirit, because the entrepreneurial spirit is very important for the company as the company could really compete in the market. In the other research by Genoveva (2019) also conclude that one of the contribution of entrepreneurial spirit is education, with entrepreneurial education the business students will be learn about business plan, team work, leadership, competitiveness, innovation and the others soft skill.

The respondents in this study were alumni of President University. Business students must have a passion to become entrepreneurs, unfortunately based on the results of previous research only about $4.21 \%$ (Senjaya \& Genoveva, 2019) from alumni of business faculty who choose to become entrepreneurs. The low number of business alumni who are interested in entrepreneurship encourages the Management of President University to change the curriculum that focuses on entrepreneurship, students are given material related to the formation of an entrepreneurial character, knowledge in the field of entrepreneurship such as making a Business Plan and applying it for one semester and continued with learning in business incubators provided by campus.

While for students who are not doing business, as they learnt about entrepreneurship, they are expected to have an entrepreneurial spirit (Maresch, Harms, Kailer, \& WimmerWurm, 2015). In addition, when they enter the workforce, they can become employees who have an entrepreneurial spirit such as innovative, creative, competitive, passion to work and always think of the best way to do their jobs. By having entrepreneurial spirit, it is expected that those who work in companies can compete with other graduates. Therefore, to become entrepreneurs or become employees, alumni of business faculty will remain success because of the entrepreneurial spirit they have within. The researchers come up with the research to analyze the entrepreneurial spirit.

\section{LITERATURE REVIEW}

\section{A. Entrepreneurial Spirit}

Today, in order to compete in the business or work place, the manager not only required the leadership skills, but entrepreneurship skills are also required (Esmer \& Dayi, 2016). The combination of leadership dan entrepreneurship skills is the combination of leaderhip qualities and entrepreneurial spirit. Dubrin (2012) state that leadership is the creativity and responsibility of leader to achieve organizational goals. In-line with Dubrin, Esmer and Dayi (2012; 2016) define that leadership is the ability influence others and bring the work plan into action for get the company target and goals. Entrepreneurial leader is a 
combination of leadership and entrepreneurial skills, both of these skills are indispensable in future business growth, so it is very important that a leader has an entrepreneurial spirit (Phaneuf, Boudrias, Rousseau, \& Brunelle, 2016). Based on the explanation, it can be concluded that, both a manager and an entrepreneur, they need an entrepreneurial spirit to be able to achieve the company's targets and bring the company to growth in the future.

Fayolle and Basso (2010) concluded that the entrepreneurial spirit, for some companies, especially largescale company is a problems, employees are required to have innovative and creative behavior, be able to adapt, be able to face problems, be able to see opportunities, maintain product popularity, can face challenges and

capture growth opportunities.

While the spirit of entrepreneurship is how someone produces something completely different from before, with higher quality, cheaper, profitable results. This activity can be carried out in all fields of work and companies (Hisrich, Grant, \& Langan-Fox, 2007). The spirit of entrepreneurship must be measurable, which means providing added value to the company. In a sense, entrepreneurship is not just for increasing profit itself, but it includes the nature and character of entrepreneurship that appears and can be learned. Existing characters include; independent and honest, business professionalism, discipline, initiative, creative, achievement oriented and future, resilient, optimistic and responsible. Existing characters include; creativity, have a professionalism in business, tenacious, optimistic, disciplined, independent and honest, have initiative, creative, achievement-oriented and futureoriented, and responsible.

\section{B. Passion of Entrepreneurship}

Passion is one of the most important factors in entrepreneurship. Successful entrepreneurs generally have a high passion. Schumpeter (2000) defined that passion is an entrepreneur behavior included rationality, uncommon risk taking, intence concentration with the business and trying hard to achieve their dream. Barron (2008) state that passions are things that motivate the actions of an entrepreneur. Highly motivated entrepreneurs not only have the desire to be involved in new business activities. They will involve themselves as entrepreneurs who have identities in all aspects of their lives (Vallerand, et al., 2007).

Passion is a deeply embedded element of entrepreneurial action (Barron, 2008; Smith, Baum, \& Locke, 2001). Going back to Schumpeter's work (1951), passion was invoked to explain entrepreneurial behavior that defines rationality, such as uncommon risk taking, intense concentration and unshakable faith in a dream. The phenomenon of passion in entrepreneurship is very often mentioned also in the popular and specialized press. Business books, interviews with entrepreneurs and autobiographies reveal passion as the main prerequisite for success in entrepreneurship. Many successful entrepreneurs credit their success to passion. Richard Branson of Virgin Group states that: "you need passion to create a truly successful business. Running a business will be a tough experience, it helps to have that passion that keep you going" *and Steve Jobs of Apple asserted that "there are many moments that are filled with despair and agony,. . . it's so hard that if you don't have a passion, you'll give up". On the other hand, academics have also turned to passion as a definitional experience of entrepreneurship.

On the other hand, entrepreneurs' passion is the role model to promote the venture performance by increasing customers and market share ( (Hofstede \& Hofstede, 2001; Cardon, Wincent, Singh, \& Drnovsek, 2009; Zhang, Bai, Caza, \& Wang, 2014; Ma, Gu, \& Liu, 2017).

Researchers can be conclude that, entrepreneurial passion is a motivation to achieve success, including the desire to always try to be better, dare to take risks, and complete all the work because they really like the job.

\section{Entrepreneurial Innovation}

Jensen, Liu and Scott (2017) found that with innovation the customers are more satisfy, because they get the better services and products. They found that, in China companies, with innovation the employees performance increasing because the job become easier and faster. The impact of the increasing of employee perfomance, the customer satisfaction also increases. In the other hand, Gronthier and Chiritia (2019) found that the impact of innovation capabilities in the parent companies consist of three stages : resources, process and values. The resources come from the incubator program, this program create more combination of employee creation. The process is act the new project development test, which are based on Business Model Canvas with focus customer unsolved problems. The values its mean the compay can get the business or market opportunity.

Shumpeter in Sledzik (2013) research state that innovation is making something less-useful become more useful. Shumpeter define 5 categories of innovation : (1)Launch a new product or a new species of existing known product, (2)Application of new method of services or products (do not proven yet in industry), (3) Opening of the new market (the market /branch / country that not represented), (4) Acquiring the new sources of supply the new raw material or the semi-finished goods and (5) New industry structure, such as the creation or destruction of a monopoly position. Shumpeter's research in Sledzik (2013) states that innovation makes things less useful to become more useful. Shumpeter defines 5 categories of innovation: (1) Generating new products or renewing existing products (2) Generating new service systems or improving service systems in a more efficient way (3) Looking for new market opportunities (markets / branches / countries that are not represented), (4) Obtaining new sources of supply of new raw materials or semi-finished goods and (5) new industrial structures, which are not monopolistic or controlled by only one company.

Okpara (2007) emphasizes that innovation is how an entrepreneur or company does new things both in term of ideas, services, products and use of existing resources to provide satisfaction to customers.

\section{Entrepreneurial Adaptability}

Jimenez, Brust, and Ubeda (2011) describe that the ability to adapt is the social ability to adapt, including the ability to plan and realize the plan included more qualified and can overcome the obstacles it faces, both now and in the future. social or physical environment. 
To adaptation of rapid change, the research of Shiferaw, Okello, Reddy (2007) and Jimenez, Brust, and Ubeda (2011) concludes that farmers in doing business must adapt, especially adaptation of resource management and conservation strategies. They must understand government policies, market changes, network marketing and rapid technological change.

Similary with some of the researchers examining, adaptability is the aspect of personal skills, the entrepreneur or manager with high adaptability can be adapt with all of situation, including ability to effectively understand others at work and use their skills to reach the organizational objectives (Zinko, Ferris, Humphrey, Meyer, \& Aime, 2012; Ferris, Douglas, Kolodinsky, \& Treadway, 2003; Powers, 2014).

\section{E. Entrepreneurial Sustainability}

Sustainable entrepreneurship is a concept that includes the overall impact of sustainable development which can be described as a desire to keep the business going forward, including contributing to employees, the environment, government and the economy at large. These contributions can have a direct or indirect impact, including giving attention to the wider community in the form of the establishment of social foundations, involving the community in the part of being a supplier of local raw materials and becoming a trainer for superior local product knowledge so that it can be maximally empowered by large companies (Crals, 2005).

Virall and Mirales (2019) results of their study concluded that entrepreneurial sustanaibility was influenced by various factors, including by actors and socio cultural. The way that can be done so that businesses survive is to create products or services that are mass, this method is done by existing companies and newcomers. In additional Schaefer, Patricia, and Kearins (2015) have the same result, to survive in business, a company must develop their products or services.

The sustanaibility entrepreneur has increased since the issue of global warming and climate change. Therefore, companies must pay attention to environmental aspects to maintain their business in the long run (Gibbs, 2006). Entrepreneurial sustainaibility can be concluded that a company or a leader must innovate their products or services and pay attention to environmental aspects in order to survive for the long term.

\section{F. Entrepreneurial Competitiveness}

According to Dess, Lumpkin and Eisner (2007) competitiveness is how to the company create the value in the market among the rivals when it pay attention to environment balance and has the advantage of internal factors. Porter (1998) states that competitive advantage is the company outperform comparing with the competitors. Porter conclude two types of company competitives advantage, differentiation and lower cost than the competitors.

While Porter (1998) regards the structure of industries emanated from 5 different factors, in the last two decades two distinctive schools of thought have emerged which are Technology-Driven and Competency-Driven approaches. According to Technology-Driven approach, information technology improves efficiency and strategic abilities. While, on the other hand, based on Competency-Driven approach, firms can identify and manage their unique competencies by internal and external stability (Booth, 2008) as an economy's competitiveness depends on its firms' competitiveness. Competitiveness is discussed in three levels of national, industrial and firm-related (Webster, 2002; Porter \& Millar, 1985).

\section{G. Performance}

Performance in this study is the performance of individuals who have an impact on organizational performance. An employee or entrepreneur is said to have a good performance if the plans that have been prepared can be implemented well and provide added value to the company's target (Short, Ketchen, Palmer, \& Hult, 2007).

The company performance also included financial performance, the indicated are sales growth, gross profit, return on investment, return on assets, return on equity. An additional, non-financial performance may include market share, reputation, re-purchase intention, customer loyalty and corporate social responsibility (Robinson \& Pearce, 1988; Dess, Ireland, \& Hitt, 1990; Antonic \& Hisrich, 2004; Kroeger, 2007).

The company's performance is determined by various factors, including the ability of employees and their leaders to make efficiency in the company's operations, including the efforts of mergers, acquisitions, diversification, organizational structure, composition and leadership style. The style of the top management team greatly influences the performance of its staff in achieving the company's goals and targets (Mankins \& Steele, 2005; King, 2007).

\section{METHODOLOGY}

This research is quantitative research by using the questionnaire for data collection, where data will be processed by using SPSS version 22 which consist of differences test (Mann Whitney), descriptive analysis,and correlation test. The researcher will test the correlation of every single variable of Entrepreneurial Spirit between Performance with compare of entrepreneur and nonentrepreneur millennials (cross section data). Figure 3.1 below represents the research framework. The entrepreneurial spirit consist of passion, innovative, adaptable, sustanaible and competitive, all of this spirit will be contribute to company performance among entrepreneurs and non entrepreneurs.

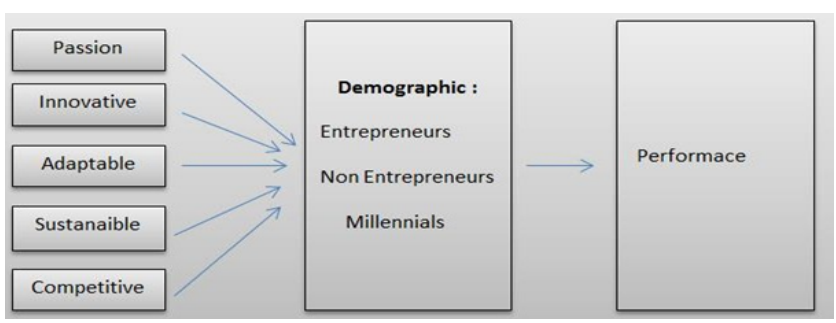

Fig. 1. Research framework

Source : (Basso \& Alain, 2010; Ehlrichman, 2015) 
Based on the research framework, the hypothesis in this study consisted of :

$\mathrm{H}_{1}$ : There are significant differences between entrepreneurs and non-entrepreneurs millennials.

$\mathrm{H}_{2}$ : Entrepreneur group have the higher entrepreneurial spirit than non-entrepreneur

$\mathrm{H}_{3}$ : There is the positive and significant correlation between Passion and Performance on entrepreneurs and non-entrepreneurs millennials.

$\mathrm{H}_{4}$ : There is the positive and significant correlation between Innovation and Performance on entrepreneurs and non-entrepreneurs millennials.

$\mathrm{H}_{5}$ : There is the positive and significant correlation between Adaptability and Performance on entrepreneurs and non-entrepreneurs millennials.

$\mathrm{H}_{6}$ : There is the positive and significant correlation between Sustainability and Performance on entrepreneurs and non-entrepreneurs millennials.

$\mathrm{H}_{7}$ : There is the positive and significant correlation between Competitiveness and Performance on entrepreneurs and non-entrepreneurs millennials.

\section{RESULTS AND DISCUSSION}

The minimum number of respondents in this study was 150 (Hair, Sarstedt, Hopkins, \& Kuppelwieser, 2014). The researchers collected 170 valid respondents using the google form. The following is the respondents profile :

TABLE I: RESPONDENT PROFILES

\begin{tabular}{|c|c|c|c|c|}
\hline Num & Ques & Answer & Freq & $(\%)$ \\
\hline \multirow{3}{*}{1} & \multirow{3}{*}{ Age } & $22-27$ & 119 & $70 \%$ \\
\hline & & $>27-32$ & 30 & $17.6 \%$ \\
\hline & & $>32-38$ & 21 & $12.4 \%$ \\
\hline \multirow{2}{*}{2} & \multirow{2}{*}{ Gender } & Male & 96 & $56.5 \%$ \\
\hline & & Female & 74 & $47.5 \%$ \\
\hline \multirow[b]{2}{*}{3} & \multirow[b]{2}{*}{ Occupation } & Entrepreneur & 29 & $17.1 \%$ \\
\hline & & $\begin{array}{l}\text { Non- } \\
\text { Entrepreneur }\end{array}$ & 141 & $82.9 \%$ \\
\hline \multirow{4}{*}{4} & \multirow{4}{*}{ Faculty } & Computing & 10 & $5.9 \%$ \\
\hline & & Humanities & 13 & $7.6 \%$ \\
\hline & & Engineering & 12 & $7.1 \%$ \\
\hline & & Business & 135 & $79.4 \%$ \\
\hline
\end{tabular}

Source: (Questionnaire, 2020)

Table 4.1 shows the results of the respondent's age, where the majority number was aged 22-27 years old with $70 \%$, following $>27-32$ years old with $17.6 \%$ and the smallest number was $>32-38$ years old with $12.4 \%$. Based on the gender, table 4.1 shows the results of female was $47.5 \%$ while male respondents were $56.5 \%$. While by respondent occupation, respondents non entrepreneur dominated as many as $82.9 \%$, and entrepreneur as much as
17.1\%. Mostly the respondent come from Business Faculty as many as $79.4 \%$, the next was Humanities Faculty as many as $7.6 \%$, while Engineering $7.1 \%$ and Computing $5.9 \%$. This result in -line with the existing students, the largest number is Business students, follow by Humanities students, however the smallest number is Engineering.

\section{Validity and Reliability Test}

A pilot test was conducted to test the validity of the questionnaire. 30 questions show results above 0.361 , the lowest score was 0.426 and he highest score was 0.893 , the meaning that all questions are valid and can be used for the next statistical process. The reliability test of Cronbach's Alpha coefficient results 0.927 (table 4.2) the indicated show the data was perfect reliability (Maholtra, 2012) Therefore all of these variables can be used for the next statistical processing stage.

TABLE II: RELIABILITY TEST

Reliability Statistics

\begin{tabular}{|c|c|c|}
\hline $\begin{array}{c}\text { Cronbach's } \\
\text { Alpha }\end{array}$ & $\begin{array}{c}\text { Cronbach's } \\
\text { Alpha Based } \\
\text { on } \\
\text { Standardized } \\
\text { Items }\end{array}$ & $\mathrm{N}$ of Items \\
\hline 924 & 927 & $\overline{6}$ \\
\hline
\end{tabular}

Source: (Questionnaire, 2020)

\section{Differences Test (Mann-Whitney)}

Based on non-parametric tests with the Mann Whitney test in table 4.3 , it can be concluded that the respondent group that as entrepreneur with those who do not as an entrepreneur are significant differences (the value of PValue $0.000<0.05)$ which means $\mathrm{H}_{1}$ is accepted. Entrepreneur group have higher performance than those who do not as an entrepreneur. This result in-line with the previous research by Klerk (1998) her study state that there is differences of entrepreneur and non-entrepreneur. De Klerk using motivation and self-efficacy as the independent variables and entrepreneurial behavior as dependent variable. Kurniasari (2008) also state the same result, her study among entrepreneur student and non-entrepreneur student, show that, that is differences of the two group.

$\mathrm{H}_{1}$ : There are significant differences between entrepreneurs and non-entrepreneurs millennnials.

TABLE III: DIFFERENCES TEST

Test Statistics ${ }^{a}$

\begin{tabular}{|c|c|}
\hline & Entrepreneur \\
\hline Mann-Whitney U & 2131.500 \\
Wilcoxon W & 3723.500 \\
Z & 2.895 \\
Asymp. Sig. (2-tailed) & .000 \\
\hline
\end{tabular}

a. Grouping Variable: Occupation

Source : (Questionnaire, 2020) 


\section{Descriptive Analysis}

Table 4.4 shows the average scores of the Likert scale (1.00-5.00) by descriptive analysis, where NonEntrepreneur respondents have the highest average for Adaptability (4.50), then Innovation (4.45), the next is Passion (4.37), number fourth was Competitiveness (4.36), the lowest was Sustainability (4.27) and Performance (4.27). While Entrepreneur has the different order, the data showed that the highest Innovation (4.33), followed by Adaptability (4.28), then Competitiveness (4.27), the next was Sustainability (4.09), number fifth was Passion (4.08) and finally Performance (3.97). To sum up, the average score of the Non-Entrepreneurs (4.37) better than Entrepreneurs (4.27), which mean $\mathrm{H}_{2}$ rejected. This conclusion is differently with the previous studies which says that entrepreneur group have a better entrepreneurial skills than non-entrepreneur group (Klerk, 1998; Gracia \& Genoveva, 2018). While, in the study of Gracia and Genoveva (2018) which examines the entrepreneurial spirit among managers, concludes that managers generally have an entrepreneurial spirit to compete and lead their department well.

$\mathrm{H}_{2}$ : Entrepreneur group have the higher entrepreneurial spirit than non-entrepreneur

TABLE IV: DESCRIPTIVE ANALYSIS

\begin{tabular}{|l|c|c|c|c|}
\hline \multirow{2}{*}{ Variable } & \multicolumn{2}{c|}{ Entrepreneur } & \multicolumn{2}{c|}{ Non-Entrepreneur } \\
\cline { 2 - 5 } & Mean & SD & Mean & SD \\
\hline Passion & 4.08 & 2.166 & 4.37 & 2.905 \\
\hline Innovation & 4.33 & 2.283 & 4.45 & 2.611 \\
\hline Adaptability & 4.28 & 1.718 & 4.50 & 2.392 \\
\hline Sustainability & 4.09 & 2.574 & 4.27 & 3.041 \\
\hline Competitiveness & 4.27 & 2.253 & 4.36 & 2.766 \\
\hline Performance & 3.97 & 2.557 & 4.27 & 3.122 \\
\hline \multicolumn{5}{|c|}{ Source : (Questionnaire, 2020) } \\
\hline
\end{tabular}

\section{Correlation Test}

The correlation in Table 4.5 below shows that Passion have a significant and positive correlation with Performance. Both of group show a strong correlation between Passion and Performance because the results in the range $0.41-$ 0.70 (Nugroho, 2005). Comparison between respondents from entrepreneur and Non-Entrepreneur shows that NonEntrepreneur has the strongest correlation, which is 0.521 and Entrepreneur group lower than Non-Entrepreneur with a value of 0.502 . Therefore, it can be concluded that hypothesis 3 is accepted. In some of the previous studies concluded that passion in very important for both entrepreneur or non-entreprenur who wants to suceed (Schumpeter J. , 1951; Vallerand, et al., 2007; Barron, 2008; Smith, Baum, \& Locke, 2001).

$\mathrm{H}_{3}$ : There is the positive and significant correlation between Passion and Performance on Entrepreneurs and Non-entrepreneurs millennials.

TABLE V: PEARSON CORRELATION

\begin{tabular}{|c|c|c|}
\hline \multirow{2}{*}{$\begin{array}{c}\text { Pearson } \\
\text { Correlation }\end{array}$} & \multicolumn{2}{|c|}{ Performance } \\
\cline { 2 - 3 } & Entrepreneur & Non-entrepreneur \\
\hline Passion & $.502^{* *}$ & $.521^{* *}$ \\
\hline Innovation & $.419^{* *}$ & $.427^{* *}$ \\
\hline Adaptability & $.502^{* *}$ & $.568^{* *}$ \\
\hline
\end{tabular}

\begin{tabular}{|c|c|c|}
\hline Sustainability & $.407^{* *}$ & $.646^{* *}$ \\
\hline Competitivenss & $.428^{* *}$ & $.612^{* *}$ \\
& \multicolumn{3}{|c|}{ Source: (Questionnaire, 2020) }
\end{tabular}

Table 4.5 in the below shows that was positive and significant correlation Innovation between Performance, both of group (Non-Entrepreneur adn Entrepreneur millennials) show the correlation area in strong (0.419 and 0.427 ) because the result range $0.41-0.70$ (Nugroho, 2005), therefore the hypothesis 4 was accepted. Innovations made by the company will make the consumers more satisfied because they get better services or products (Jensen, Liu, \& Scott, 2017; Schumpeter J. A., 2000). Likewise for an entrepreneur, the innovation will be lead to satisfaction for entrepreneurs themselves and consumers (Gronthier \& Chirita, 2019).

$\mathrm{H}_{4}$ : There is the positive and significant correlation between Innovation and Performance on Entrepreneurs and Non-entrepreneurs millennials.

In table 4.5 above, it can be seen that Entrepreneur and Non-entrepreneur millennials showed significant results and positive correlations, both of them showed strong correlations. The correlation between Adaptability and Performance in Non-Entrepreneur Millennials was higher (0.568) compared to Entrepreneur millennilas (0.502), although both still showed strongth correlations (Nugroho, 2005). Therefore, it can be concluded that hypothesis 5 was accepted. Adaptability is really needed for entrepreneurs and non-entrepreneurs in the business. Those who are able to adapt will have better performance and can increasing their business (Ferris et al, 2003; Jimenez, Brust and Edabeda, 2011; Jimenez, Brust and Edabeda, 2011). Zinko et al, 2012; Powers, 2014)

$\mathrm{H}_{5}$ : There is the positive and significant correlation between Adaptability and Performance on Entrepreneurs and Non-entrepreneurs millennials.

Sustainability and Performance in table 4.5 show that Non-Entrepreneur and entrepreneur millennials have significant and positive correlations. Non-Entrepreneurs (0.646) and Entrepreneur (0.407) millennials showed strong correlations because they had results range $0.41-0.70$ (Nugroho, 2005). We can conclude that hyphothesis 6 was accepted. Many studies say that sustainability is correlated with performance, therefore a company that is able to continue is a company that has good performance, including environmental aspects and business sustainability in the long term (Schaefer, Patricia, and Kearins (2015) ; Virall and Mirales (2019); (Gibbs, 2006).

$\mathrm{H}_{6}$ : There is the positive and significant correlation between Sustainability and Performance on Entrepreneurs and Non-entrepreneurs millennials.

In table 4.5 above, it can be seen that Non-Entrepreneur and Entrepreneur showed significant results and positive correlations, both of correlation between Competitiveness and Performance was strong $(0.41-0.70)$ according to Nugroho, 2005. Compared to Non-Entrepreneur (0.612) with Entrepreneur (0.428), Non-Entrepreneur has higher 
correlation than Entrepreneur. Therefore, it can be concluded that hypothesis 7 was accepted. Over the past several decades, researchers have found that there is a strong correlation beetwen competitiveness and performance, this study also shows the same thing in groups of entreprenurs and non-entrepreneurs (Porter \& Millar, 1985; Porter M. , 1998; Dess, Ireland, \& Hitt, 1990).

$\mathrm{H}_{7}$ : There is the positive and significant correlation between Competitiveness and Performance on Entrepreneurs and Non-entrepreneurs millennials.

\section{CONCLUSION AND RECOMMENDATION}

\section{Conclusion}

Entrepreneurship spirit is a crucial point for both entrepreneur and non-entrepreneur for company reaching their business competitiveness. Therefore, entrepreneurial spirit in this research variables (passion, innovation, adaptability, sustainability and competitiveness) will be impact to company performance both of financial and non financial aspects. The company is expected to not only be established as much as possible but only to last for a moment. Sustainability of the company is very important.

Based on the analysis the group of Entrepreneur and NonEntrepreneur, the conclusion of this research is there is a difference on the entrepreneurial spirit of the alumni of President University who are the Entrepreneur and Nonentrepreneur. In correlation there is a positive and strong correlation of Passion, Innovation, Adaptability, Sustainability and Competitiveness to Performance of Entrepreneurs and Non-Entrepreneurs millennials. While, by descriptive analysis, millennials of the NonEntrepreneurs have a higher mean compared with the millennials who are entrepreneurs.

By hypothesis, one hypothesis is rejected and six hypothesis are accepted. Therefore, that is need to explore more by the future research for the entrepreneurial spirit of entrepreneur and non-entrepreneur.

TABLE VI: RESULT OF HYPOTHESES

\begin{tabular}{|c|l|c|}
\hline Hypothesis & \multicolumn{1}{|c|}{ Statement } & Result \\
\hline $\mathrm{H}_{1}$ & $\begin{array}{l}\text { Differences between Entrepreneurs } \\
\text { and Non-entrepreneurs } \\
\text { millennials. }\end{array}$ & Accepted \\
\hline $\mathrm{H}_{2}$ & $\begin{array}{l}\text { Entrepreneur group have the higher } \\
\text { Entrepreneurial spint than Non- } \\
\text { entrepreneur }\end{array}$ & Rejected \\
\hline $\mathrm{H}_{3}$ & Passion-> Performance & Accepted \\
\hline $\mathrm{H}_{4}$ & Innovation-> Performance & Accepted \\
\hline $\mathrm{H}_{5}$ & Adaptability $>$ Performance & Accepted \\
\hline $\mathrm{H}_{6}$ & Sustainability->Performance & Accepted \\
\hline $\mathrm{H}_{7}$ & Competitiveness-> Performance & Accepted \\
\hline
\end{tabular}

\section{Recomendation}

The university can be provided special courses for the students who want start up or continuing their family business. The courses should be combines of soft skills such as passion, adaptability, performance and entrepreneurial spirit. The university can be also provides seminar, mentorship, applied training, workshop and incubator business for increasing the student'S knowledge. The alumni should be have the entrepreneurial spirit to gain competitive advantages (Esmer and Dayi, 2017). For the future researcher, this research can be more usefull if using bigger number of respondents, combination the other demographic for analysis the data. The future researcher also can be using the other variables such as education background, family background, motivation and selfefficacy.

\section{ACKNOWLEDGMENT}

This reserch funding by internal grant of Research and Social Community Department, President University, 2019.

\section{REFERENCES}

Antonic, B., \& Hisrich, R. (2004). Corporate Entrepreneurship Contingencies and Organizational Wealth Creation. Journal of Management Development, 23(6), 518-550.

Barron, R. (2008). The Role of Affect in the Entrepreneurial Process. The Academy of Management Review, 33(2). doi:10.5465/AMR.2008.31193166

Basso, O., \& Alain, F. (2010). Entrepreneurial Spirit and Corporate Entrepreneurship in Large Companies. International Journal of Entrepreneurship and Small Business, 10(3), 307-322. doi:10.1504/IJESB.2010.033570

Booth, P. (2008). The Transition from Social Insecurity. Economic Fairs, 18(1), 2-12. doi:https://doi.org/10.1111/1468-0270.00068

Cardon, M. S., Wincent, J., Singh, J., \& Drnovsek, M. (2009). The Nature and Experience of Entrepreneurial Passion. Academy of Management Review, 34(3). doi:https://doi.org/10.5465/amr.2009.40633190

Dess, G. G., Lumpkin, G. T., \& Eisner, A. B. (2007). Strategic Management: Creating Competitive Advantages. Irwin: McGraw-Hill/Irwin.

Dess, G., Ireland, R., \& Hitt, M. (1990). Industry Effects and Strategic Management Research. Journal of Management, 16, 7-27.

Drucker, P. F. (1985). Innovation and Entrepreneurship. United Kingdom: Post Capitalist Society.

Dubrin, A. J. (2012). Leadership: Research Findings, Practice, and Skills. Mason: Erin Journey.

Ehlrichman, M. (2015). 5 Characteristic of Entrepreneurial Spirit. Start Up Porch.com.

Esmer, Y., \& Dayi, F. (2016). Entrepreneurial Leadership: A Theoritical Research. 25th International Academic Conference (pp. 157165). Paris: OECD Headquarters. doi:10.20472/IAC.2016.025.020

Ferris, G., Douglas, C., Kolodinsky, R. W., \& Treadway, D. C. (2003). Personal Reputation in Organization. In J. Greenberg, Organizational behavior: The State of the Sicence (pp. 211246). Mahwah, NJ: Lawrence Erlbaum.

Genoveva. (2019). The Influence of Entrepreneurial Culture on Entrepreneurial Intention Among Business Students. FIRM Journal of Management Studies, 4(1), 40-56.

Gibbs, D. (2006). Sustainable Entrepreneurs, Ecopreneurs, and The Development of A Sustainable Economy. Greener Management International, 55, 63-78.

Gracia, M., \& Genoveva. (2018). The Intrapreneurial Spirit of Managers in Jabodetabek. Seminar Nasional Kewirausahaan dan Inovasi Bisnis VIII (pp. 429-438). Jakarta: Tarumanegara Universitty.

Gronthier, J., \& Chirita, G. M. (2019). The Role of Corporate Incubators as Invigorators of Innovation Capabilities in Parent Companies. Journal of Entrepreneurship and Innovation, 8(8), 1-21. doi:https://doi.org/10.1186/s13731-019-0104-0

Hair, J., Sarstedt, M., Hopkins, L., \& Kuppelwieser, V. G. (2014). Partial Least Squares Structural Equation Modelin (PLS-SEM). Los Angeles: Emerald Insight.

Hofstede, G., \& Hofstede, G. (2001). Culture's Consequences: Comparing Values, Behaviors, Institutions, and Organizations Across Nations. Thousand Oaks, CA: Sage Publications.

Jensen, K. W., Liu, Y., \& Scott, T. (2017). Entrepreneurs Innovation Bringing Job Satisfaction, Work-Family Balance and Life Satisfaction: In China and Around the World. International Journal of Innovation Study, 1, 193-206. 
Jiménez, J. D.-B., Brust, D. V., \& Úbeda, J. P. (2011). Adaptability, Entrepreneurship and Stakeholder Integration: Scenarios and Strategies for Environment and Vulnerability. Journal of Environmental Protection, 2(10), 1375-1387. doi:10.4236/jep.2011.210160

Klerk, A. D. (1998). Variables distinguishing entrepreneurs and nonentrepreneurs from different ethnic groups in the South African environment, University of South Africa, Pretoria.

Kroeger, J. W. (2007). Firm Performance as A Function of Entrepreneurial Orientation and Strategic Planning Practices. Cleveland State University.

Kurniasari, N. I. (2008). Perbedaan Karakteristik Entrepreneurial Antara Entrepreneur Student dan Non-Entrepreneur Student.

Ma, C., Gu, J., \& Liu, H. (2017). Entrepreneurs's Passion and New Venture Performance in China. International Entrepreneurship and Management Journal.

Maholtra, N. K. (2012). Basic Marketing Strategy: Pearson.

Maresch, D., Harms, R., Kailer, N., \& Wimmer-Wurm, B. (2015). The impact of entrepreneurship Education on The Entrepreneurial Intention of Students in Science and Engineering Versus Business Studies University Programs. Technological Forecasting and Social Change, 104. doi:10.1016/j.techfore.2015.11.006

Nugroho, A. (2005). Strategi Jitu Memilih Metode Statistic Penelitian Dengan SPSS. Yogyakarta.

Okpara, F. O. (2007). The Value of Creativity and Innovation in Entrepreneurship. Journal of Entrepreneurship and Sustainability, $\operatorname{III}(2)$.

Phaneuf, J.-É., Boudrias, J.-S., Rousseau, V., \& Brunelle, É. (2016). Personality and Transformational Leadership: The Moderating Effect of Organizational Context. Personality and Individual Differences, 102 ,

30-35. doi:https://doi.org/10.1016/j.paid.2016.06.052

Porter, M. (1998). The Competitive Advantage: Creating and Sustaining Superior Performance. New York: Free Press.

Porter, M. E., \& Millar, V. A. (1985). How Information Gives You Competitive Advantage. Harvard Business Review, 63(4), 149160.

Powers, C. L. (2014). The Importance of Adapting the Others: Interpresonal Theory as A Means to Examine Adaptability at Work. Unpublished Dissertation: Michigan State University.

Robinson, R., \& Pearce, A. (1988). Planned Patterns of Strategic Behavior and Their Relationship to Business-Unit Performance. Strategic Management Journal, 9, 43-60.

Schaefer, K., Particia, D., \& Kearins, K. (2015). Social, Environmental and Sustainable Entrepreneurship Research: What is Needed for Sustainability-as-Flourishing? Organization and Environment, 28(4), 394-413.

Schumpeter, J. (1951). Imperialism and Social Classes. New York: Meridian Books

Schumpeter, J. A. (2000). Entrepreneurship As Innovation. Entrepreneurship: The Social Science View, 51-75. Retrieved from https://ssrn.com/abstract=1512266

Shiferaw, B. A., Okello, J., \& Reddy, R. V. (2007). Adoption and Adaptation of Natural Resource Management Innovations in Smallholder Agriculture: Reflections on Key Lessons and Best Practices. Environment and Development Sustainability, 11, 601-619.

Sledzik, K. (2013). Schumpeter's View on Innovation and Entrepreneurship. SSRN Electronic Journal, 89-93. doi: $10.2139 /$ ssrn. 2257783

Smith, K. G., Baum, J. R., \& Locke, E. A. (2001). A Multi-Dimensional Model of Venture Growth. The Academy of Management Journal, 44(2), 292-301. doi:10.2307/3069456

Vallerand, R. J., Salvy, S.-J., Mageu, G. A., Elliot, A. J., Denis, P. L., Grouzet, F. M., \& Blanchard, C. (2007). On The Role of Passion in Performance. Journal of Personality, 75(3), 505-534. doi: https://doi.org/10.1111/j.1467-6494.2007.00447.x

Virral, \& Miralles. (2019). Entrepreneurship in Response to Grand Challenges: What Do We Know and How Do We Know Forward. Business and Economic Revieew, 28(3), 102-111.

Webster, M. (2002). Supply System Structure, Management, and Performance (A Conceptual Model). International Journal of Management Review, 353-369. doi:https://doi.org/10.1111/1468-2370.00092

Wirawan, C. (2012). Open Innovation to Sustain Indonesia SMEs. Procedia Economics and Finance, 4, 223 - 233.

Zhang, G., Bai, Y., Caza, A., \& Wang, L. (2014). Leader Integrity and Organizational Citizenship Behaviour in China. Management and Organization Review, 10(2), 299-319.
Zinko, R., Ferris, G., Humphrey, S., Meyer, C., \& Aime, F. (2012) Personal Reputation in Organizations: Two- Study Constructive Replication and Extension of Antecedents and Consequences. Journal of Occupational and Organizational Psychology, 85, 156-180.

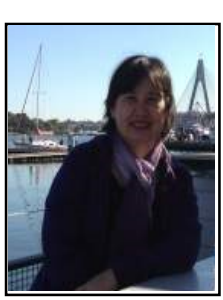

Genoveva is a associate Proffesor and Head of Management Study program of School of Business, President University. She has been published more than 30 articles in national and international journals. Her research focuses on entrepreneurship, family business, branding and green marketing.

Genoveva is doctorate in marketing and practises her knowledge as an adviser in her family business and consultant for start up business. Some of her publications related with her experiances in family business, such as (1) A Comparison of Baby Boomers and Millennials Generation in Family Business Performance, (2) Less Intention to Apply in Family Business: Millennials' Perpectives (3) The Influence of Motivation, Market Orientation and Organizational Learning towards Dealers Performance (A Case Study of Yamaha Motorcycle Entrepreneurs).

Dr. Genoveva is membership of Association of Bachelor Economics Indonesia and reviewer for national accredited journal FIRM : Journal of Management Studies and some of international journal such as Sky Journal of Business Administration and Management, International Journal of Entrrepreneurship. She also got some of awards in publication: such as (1) The best presenter of International Seminar On Scientific Issues and Trends, Bekasi, Indonesia, 2014 (2) The best Paper of International Conference of Economics and Social Science, Bangkok, Thailand, 2017; (3) The best paper of Business and Economics National Conference, Jakarta, Indonesia, 2019.

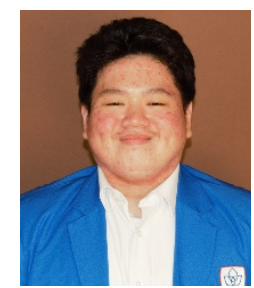

Jason Tanardi as the second authors is a final year international business student at President University, Indonesia. Jason is currently the research assistant for the Head of Management Study Program, Genoveva, the first author on this research. His research field of study focuses on entrepreneurship, sustainability, consumer behavior, and corporate social responsibility.

Some of his research paper were related with the some field of studies; (1) Green Entrepreneurship: A New Paradigm for Millennials in Indonesia, (2) Intra-Logistic Strategy Analysis on Tokopedia Self-Courier to Face the Industry 4.0, (3) Setting Social Media Strategy to Boost Generation Z Intention to Visit National Historical Museum in Jakarta.

Jason has nominated as one of the winner member of World Islamic Economic Forum 2019 in Penang Malaysia with the theme of Smart Tourism. He is also the top 9 finalist for National Scientific Paper in State University of Surabaya. He is also the $2^{\text {nd }}$ winner for the China Harbor Engineering Company Scholarship in 2020. 
